\section{The Provincial Universities of Great Britain}

TN the October (1931) issue of the Universities Review, Prof. E. R. Dodds opened a discussion on the question, "What is Wrong with the Modern Universities ?" Further articles in the April issue carry the matter on another stage. These outspoken essays are in general agreement as to there being ample grounds for the implied assumption of failure to realise an ideal, and incidentally testify to the value of Dr. Abraham Flexner's recent work, "Universities: American, English, German", in stimulating thought on the subject.

Most students of the modern universities are, according to Prof. W. M. Tattersall, whose presidential address to the Association of University Teachers is reproduced in the April issue of the Review, uncivilised and, in a broad sense, uneducated. They are conspicuously lacking in that bildung which Flexner holds to be characteristic of the product of the ancient universities. Prof. Tattersall attributes this largely to the fact that only a small percentage of the students are able to live in colleges or hostels, the larger number living either at home or in lodgings. Pending or failing the provision of a complete and compulsory residential system, an organised effort should be made to promote informal and social contacts between staff and students. He suggests, and the scheme is not without precedents, that the students should for this purpose be allotted in groups to members of the staff, each of whom would act in the capacity of 'moral' tutor to the group assigned to him (or her).

In an article headed "University Uniformity", in the same issue, Prof. R. C. McLean observes that the root of the trouble with our local universities is that they are so intensely local. He is in favour of spells of wage-earning during the study years and migration between universities. Two other articles discuss the same problem with special reference to the large proportion of the students of the modern universities who are destined for the teaching profession.

The teacher-training departments occupy in the modern provincial universities a position peculiarly favourable for estimating the effects of the educational processes at work in the arts and pure science departments. The diploma course of these departments includes graduates from many different schools of the university, and while pursuing it they show 'the mettle of their pasture'. 'It is fitting, therefore, that there should be two articles by members of the staffs of teacher-training departments, namely, Profs. F. A. Cavenagh and J. F. Duff. Both are of opinion that students suffer from being over-taught in the effort to cover the whole of the ground defined by an elaborately prescribed syllabus, with the result that they have little time for spontaneous learning.

Since lectures cannot be dispensed with or the lecture programme greatly reduced while the students are so numerous in proportion to the staffs, the remedy, suggests Prof. Cavenagh, lies in improving the lectures. Too many university teachers give but little thought to their teaching as an art in itself, regarding skill in teaching as something that comes by itself or is beneath the notice of a competent scholar. The 'research' fetish, moreover, has largely ousted the ideal of the well-educated, well-read student with more than one intellectual interest. Both articles direct attention to the evil results that follow in many cases the choice by students of a highly specialised course merely because it seems the only avenue to the goal of a 'good honours degree", notwithstanding that a less specialised course would be more congenial and of greater practical utility.

\section{University and Educational Intelligence}

CAMbridge.-The Managers of the Balfour Fund have made the following grants: (1) $£ 100$ to I. T. Sanderson, of Trinity College, for an investigation of the land vertebrate fauna of the Cameroons : (2) $£ 30$ to D. L. Serventy, of Gonville and Caius College, for a biological survey of the East Anglian estuaries.

W. E. Candler, scholar of Trinity College, has been elected to the Sheepshanks Exhibition.

The Council of the Senate recommends that the readership in ethnology be discontinued, and that there be established a William Wyse professorship of social anthropology, which shall be held in the first instance by Col. T. C. Hodson, of Christ's College.

The General Board recommends that the subject of pharmacology be placed under the superintendence of the professor of physiology in the Department of Physiology, and that the University lectureship in pharmacology be transferred from the Faculty of Medicine to the Department of Physiology in the Faculty of Biology $B$.

The Board of Research Studies has approved Mr. U. R. Evans, of King's College, for the degree of Sc.D.

A Research Studentship at Emmanuel College, of the maximum annual value of $£ 150$, will be awarded in July. Preference will be given to candidates who have already completed one but not more than two years of research. Applications, including a statement of the proposed course of research, must reach the Master, Emmanuel College, Cambridge, not later than June 30 .

OXFORD.-On May 24, Congregation passed a decree acknowledging with gratitude the offer of the Rockefeller Foundation to contribute a sum not exceeding $2,300,000$ dollars, together with an additional 10 per cent of the estimated cost of construction, towards the extension of the Bodleian Library ; on condition that the University shall have received for the same purpose a total of $£ 377,720$ before the end of 1936 . In proposing the adoption of the decree, the Warden of New College mentioned that the scheme included the addition of a new wing to the Radcliffe Science Library at the Museum.

THREe post-graduate scholarships in pure and applied science are being offered by University College, Nottingham. The value of each is $£ 100$, and they are tenable for one or two years. Forms of application, returnable by July 21 , can be had from the Registrar of the College.

\section{Calendar of Geographical Exploration}

\section{June 5, r 594.--Barents in the Arctic}

A Dutch expedition, with William Barents (Willem Barentszoon) in charge of one ship, the Mercurius, sailed from Texel to search for the North Sea route to the east. Barents on this voyage discovered and explored the northern part of Novaya Zemlya. Two of the other vessels that left the Texel on that date were in charge of Jan Huyghen van Linschoten, a distinguished Dutch mariner, and they penetrated into the Kara Sea. Linschoten's report resulted in the sending of a second Dutch expedition in 1595 , which, however, was compelled by ice and contrary winds to return when it had barely entered the Kara Sea. A third Dutch expedition, this time organised by the city of Amsterdam, sailed on May 10, 1596, with William Barents as chief pilot. They discovered Bear Island and part of Spitsbergen, which Barents, however, thought was Greenland. On returning to Bear Island, Barents sailed south and the other ship 